\title{
Facial rehabilitation with implant-retained nasal prosthesis of acrylic resin: a case report
}

\author{
Reabilitação facial com prótese nasal em resina acrílica \\ implanto-retida: relato de caso clínico
}

\author{
Cássio Raniere Gomes do AMARAL1 ${ }^{1}$ https://orcid.org/0000-0001-7842-9040 \\ Marcelo Barbosa RAMOS ${ }^{1}$ iD https://orcid.org/0000-0002-7867-1678 \\ Márcia Gabrielle Mendes FERNANDES ${ }^{1}$ iD https://orcid.org/0000-0002-9241-5419 \\ Romulo Rocha REGIS ${ }^{1}$ iD https://orcid.org/0000-0003-2900-7815 \\ Tauane Cavalcante DINIZ1 ${ }^{\text {iD }}$ https://orcid.org/0000-0002-3564-3108
}

Wagner Araújo de NEGREIROS ${ }^{1}$ iD https://orcid.org/0000-0003-2602-8610

\begin{abstract}
The objective of this study was to report a clinical case of facial rehabilitation with an acrylic implant-retained nasal prosthesis after partial rhinectomy resulting from the resection of a basal cell carcinoma in the patient, a 53-year-old Caucasian, normosystemic, professional cowboy. After clinical examination and in possession of computed tomography images, surgery was performed for the placement of conventional dental implants in the premaxillary region (left side). After the surgery, a three-month period of waiting was observed to allow osseointegration of the implants. Later, the nasal prosthesis was prepared, and at the end of treatment, this presented satisfactory peripheral adaptation, retention and esthetics. The patient has returned for follow-up every 6 months, regarding analysis of the prosthesis color, peri-implant health, hygiene, and exchange of the magnets and relays when necessary. The authors concluded that this therapy may be well indicated in patients with partial and total nasal defects, provided that there is correct planning and execution of the surgical, clinical and laboratory phases.
\end{abstract}

Indexing terms: Carcinoma, basal cell. Face. Rehabilitation.

\section{RESUMO}

O objetivo deste trabalho é relatar um caso clínico de reabilitação facial com prótese nasal acrílica implanto-retida pós-rinectomia parcial decorrente da ressecção de um carcinoma basocelular em um paciente do sexo masculino, vaqueiro, 53 anos de idade, caucasiano e normossistêmico. Após exame clínico e de posse da tomografia computadorizada, foi realizada a cirurgia de instalação dos implantes dentários convencionais na região da pré-maxila (lado esquerdo). Depois de realizada a cirurgia, esperou-se a osseointegração dos implantes por três meses e, posteriormente, foi realizada a confecção da prótese nasal que, ao final do tratamento, apresentou adaptação periférica, retenção e estética satisfatórias. O paciente tem retornado a cada 6 meses para proservação quanto à análise da

$\checkmark v \nabla v$

1 Universidade Federal do Ceará, Faculdade de Farmácia, Odontologia e Enfermagem. Rua Alexandre Baraúna, 949, 60430-160, Rodolfo Teófilo, Fortaleza, CE, Brasil. Correspondence to: CRG AMARAL. E-mail: <odontolife19@hotmail.com>.

$\boldsymbol{v} \boldsymbol{v} \boldsymbol{v}$

How to cite this article

Amaral CRG, Ramos MB, Fernandes MGM, Regis RR, Diniz TC, Negreiros WA. Facial rehabilitation with implant-retained nasal prosthesis of acrylic resin: a case report. RGO, Rev Gaúch Odontol. 2021;69:e2021002. http://dx.doi.org/10.1590/1981-863720210000120180039 
cor da prótese, saúde periimplantar, higienização, troca dos magnetos e reembasamentos quando necessários. Os autores concluem que essa terapia pode ser bem indicada em defeitos nasais parciais e totais, desde que haja correto planejamento e execução das fases cirúrgica, clínica e laboratorial.

Termos de indexação: Carcinoma basocelular. Face. Reabilitação.

\section{INTRODUCTION}

The face is the most sensitive region of the body, and many individuals suffer with facial tissue defects. These patients have their social and psychological life impaired due to functional and aesthetic problems [1]. Rehabilitating these patients with craniofacial deformities, whether congenital or acquired, has been a challenge for multidisciplinary teams [2].

Facial reconstruction can be performed through different approaches as plastic surgery, maxillofacial prosthesis or by association of both modalities [3]. The location, size, etiology of the defect, the age of patient, the general medical condition and the patient response are variables used to determine the most appropriate reconstruction method [4].

Surgical plastic repair of facial deformities has produced satisfactory results in most cases, as long as local and general conditions are favorable to such a procedure. This method is chosen when circumstances are appropriate, and should be the first alternative, since autoplastic repair (performed with living tissue) is more desirable than any alloplastic substitute1. Rehabilitation with maxillofacial prostheses is a treatment option when the surgical approach alone cannot restore the defect. [3].

Among the etiologies of buccomaxillofacial defects, surgical resection of malignant pathologies is the most common cause. In these cases, most diagnoses are made at an advanced stage of the disease, which implies treatment with mutilation of the patient [5].

Skin cancer is the most frequent in all populations. It presents itself, basically, in two forms: melanoma and non-melanoma. Among non-melanoma cancers, basal cell and squamous cell (or epidermoid) carcinomas are the most frequent. The highest incidence rates of skin cancer, melanoma and non-melanoma have been observed in countries with high prevalence of caucasian population. For the non-melanoma type, in particular for squamous cell carcinoma, the incidence increases with age and is more frequent in the male population. The main risk factor for skin cancer, for both melanoma and non-melanoma, is excessive exposure to solar radiation [6].
The nasal pyramid is the most frequent site of skin tumors such as basal cell carcinoma, squamous cell carcinoma and melanoma, which must be treated surgically. In some cases, the safety margin can be corrected by plastic surgery, or the defect can be left open due to the possibility of recurrence, which can often determine the total or partial resection of the nasal pyramid $[7,8]$.

The nose is the anatomical unit positioned in the central third of the face and is of fundamental importance, because, in addition to heating, humidifying and purifying the air, adapting it to reach the lungs, it defines the physiognomy, being responsible for the individual's phenotypic characterization. It consists of three layers (mucosa, osteocartilaginous framework and skin), its surface being full of anatomical curves and depressions [9]. The nose is an unique organ on the face, so it is difficult to conceal its loss, in addition to causing breaks in normality, harmony and facial balance [10].

The restorative nasal prosthesis is the type of facial prosthesis that proposes to alloplastic reconstruction of the loss of substances on the nasal pyramid [11]. This type of prosthesis restores the facial contour, protects the delicate remaining structures, keeps the mucous membrane that lines the passage of air moist and free from irritation, allows the restoration of nasal resonance and acts as a compensatory benefit for the patient's psychological adaptation to his new condition [10].

The present study aims to report a clinical case of a prosthetic facial rehabilitation after rhinectomy of a patient patient attended at the NUFACE clinic (Facial Defects Rehabilitation (linic) at the Federal University of Ceará (Fortaleza, Ceará, Brazil), clinical reference in the rehabilitation of patients with buccomaxillofacial defects.

\section{CASE REPORT}

RS patient, male, 53 years old, caucasian, cowboy and resident in Morada Nova, Ceará, Brazil, presented to the Face Defects Center after partial rhinectomy of the nasal pyramid (left side), resulting from resection of malignant neoplastic lesion, for rehabilitation with partial 
nasal prosthesis of acrylic resin, implant-retained and with magnetic retention.

Anamnesis and physical examination of the face were performed to analyze the residual nasal cavity (figure 1). He was also asked to sign the Informed Consent Term (appendix I) and the clarification term on the prosthetic rehabilitation treatment of the NUFACE Clinic (appendix II), containing information about the proposed treatment and the authorization of the photographic record and the use of the clinical case for scientific purposes.

Morse taper implants were installed in the left premaxilla six months before (Titamax WS Cortical implants, 5.0 × 5 mm, Neodent, São Luis, MA, Brazil) (figure 2). After the surgical exposure of the two implants,

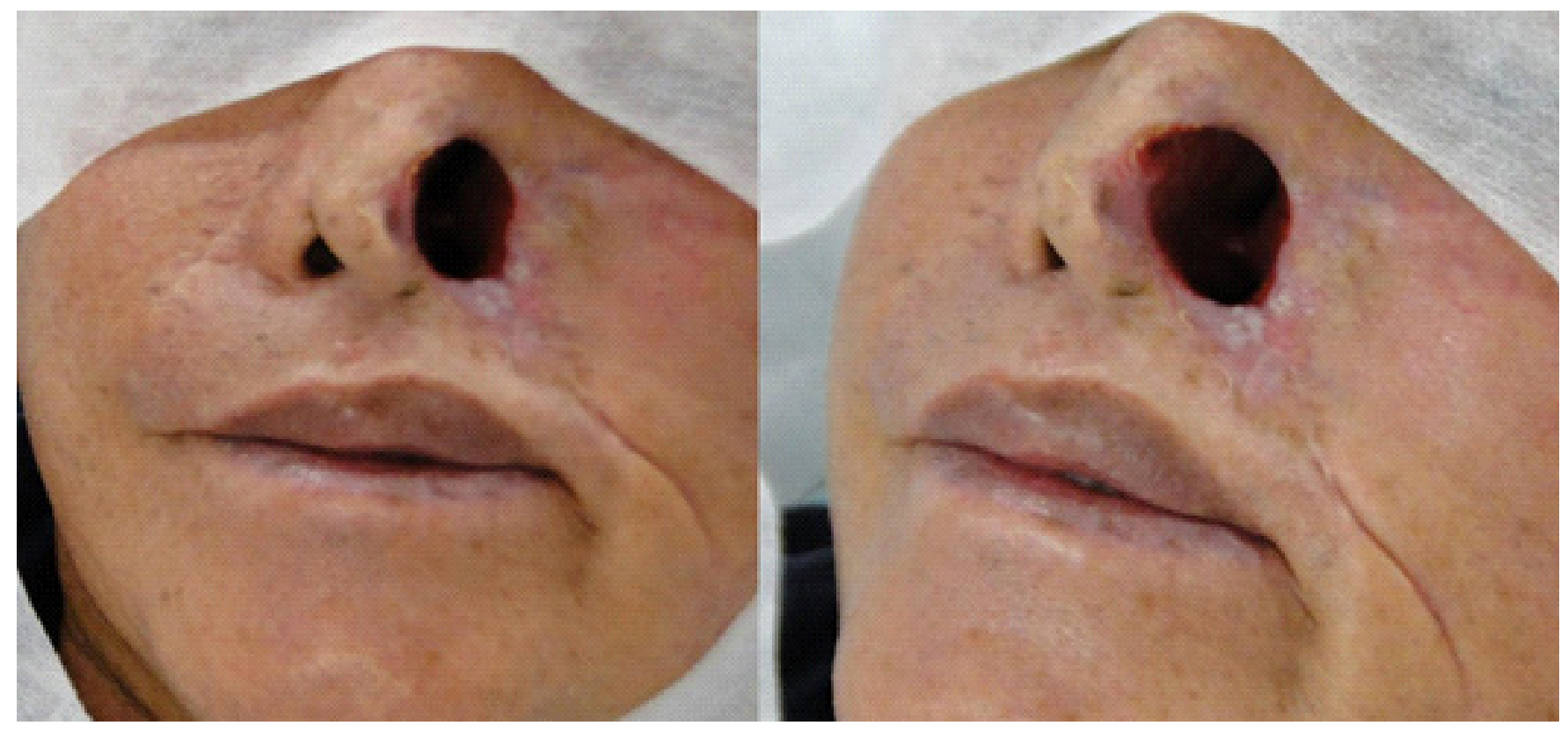

Figure 1. Initial frontal and lateral view of the nasal deformity.

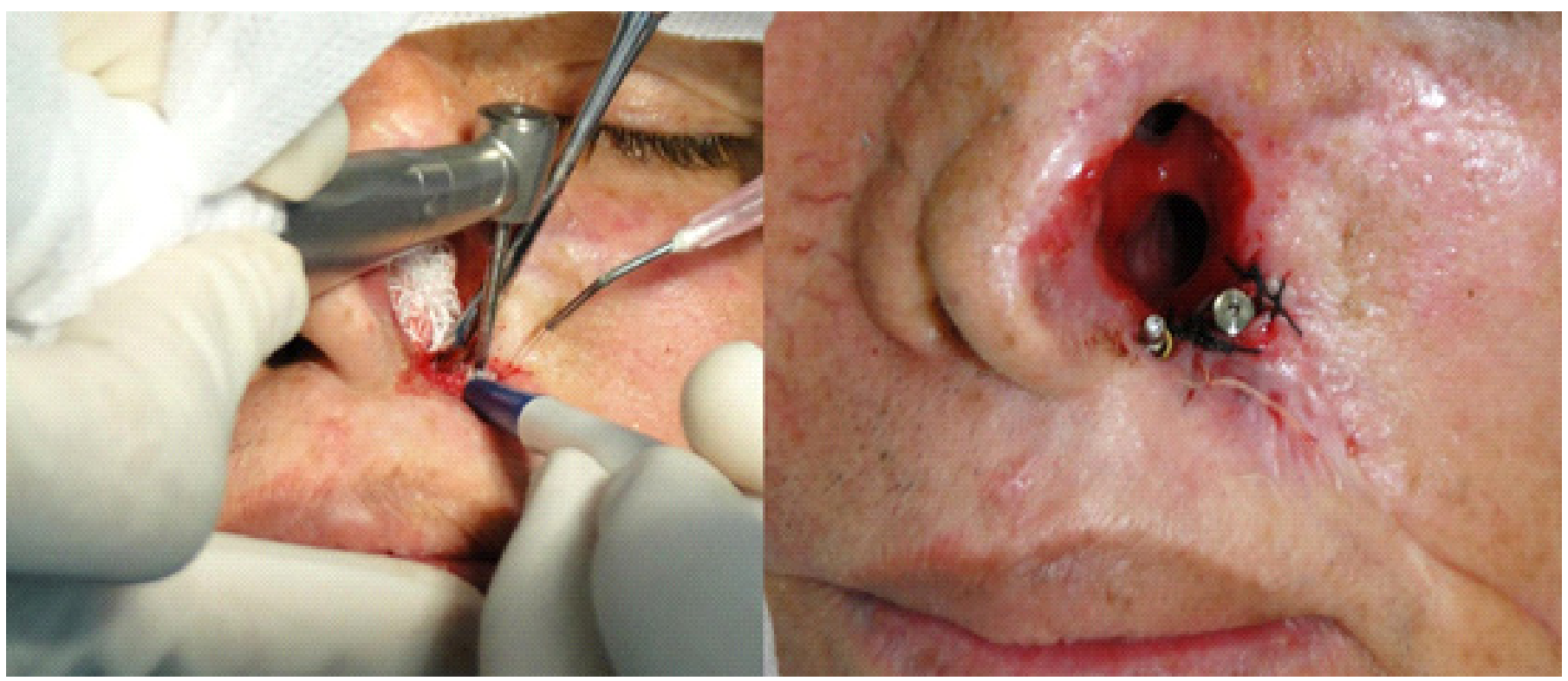

Figure 2. Surgical procedure for installing two short Morse taper connection implants. 
the tapered mini-abutments were screwed and on them the respective transfer components to perform the transfer molding of the position of the implants to the working model (figure 3). The technique was carried out with the transference union by means of a braid of dental floss and, on this, Duralay acrylic resin (Dencrilay Autopolymerizable Acrylic Resin, Dencril Produtos Odontológicas, Caieiras, SP, Brazil), using the brush-on technique (powder and liquid), thus obtaining the transfer complex.
The material of choice for the transfer molding was the condensation silicone (Condensation Silicone Profile, Coltene, Rio de Janeiro, RJ, Brazil). On the transfer complex, and on the area to be molded, the light paste was taken in an elastomer syringe (Polidental Silicone Injector, Parque Alexandre - Cotia, SP, Brazil) and, on this and on the remaining nasal pyramid, the heavy paste. The defect was previously protected with gauze embedded with solid petroleum jelly in order to prevent the entrance of the impression material into the cavity to be avoided.

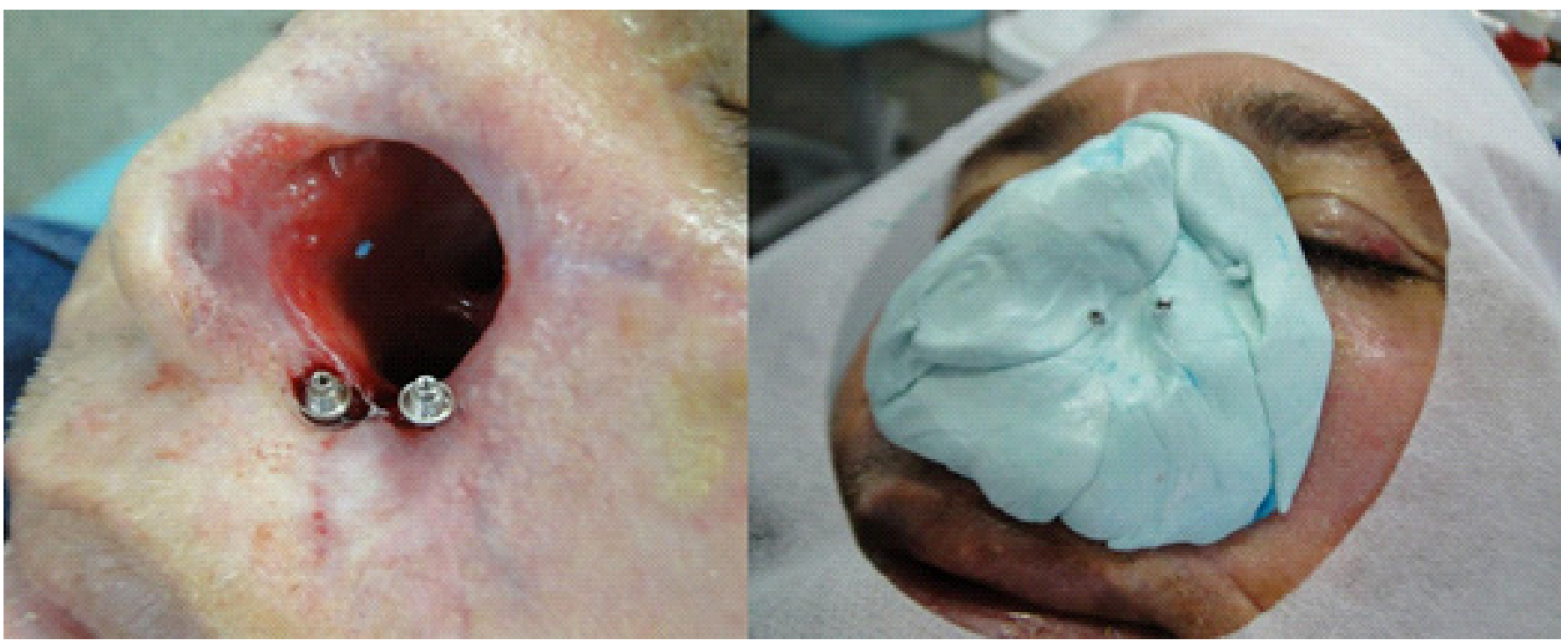

Figure 3. Installation of conical mini-abutments and molding step.

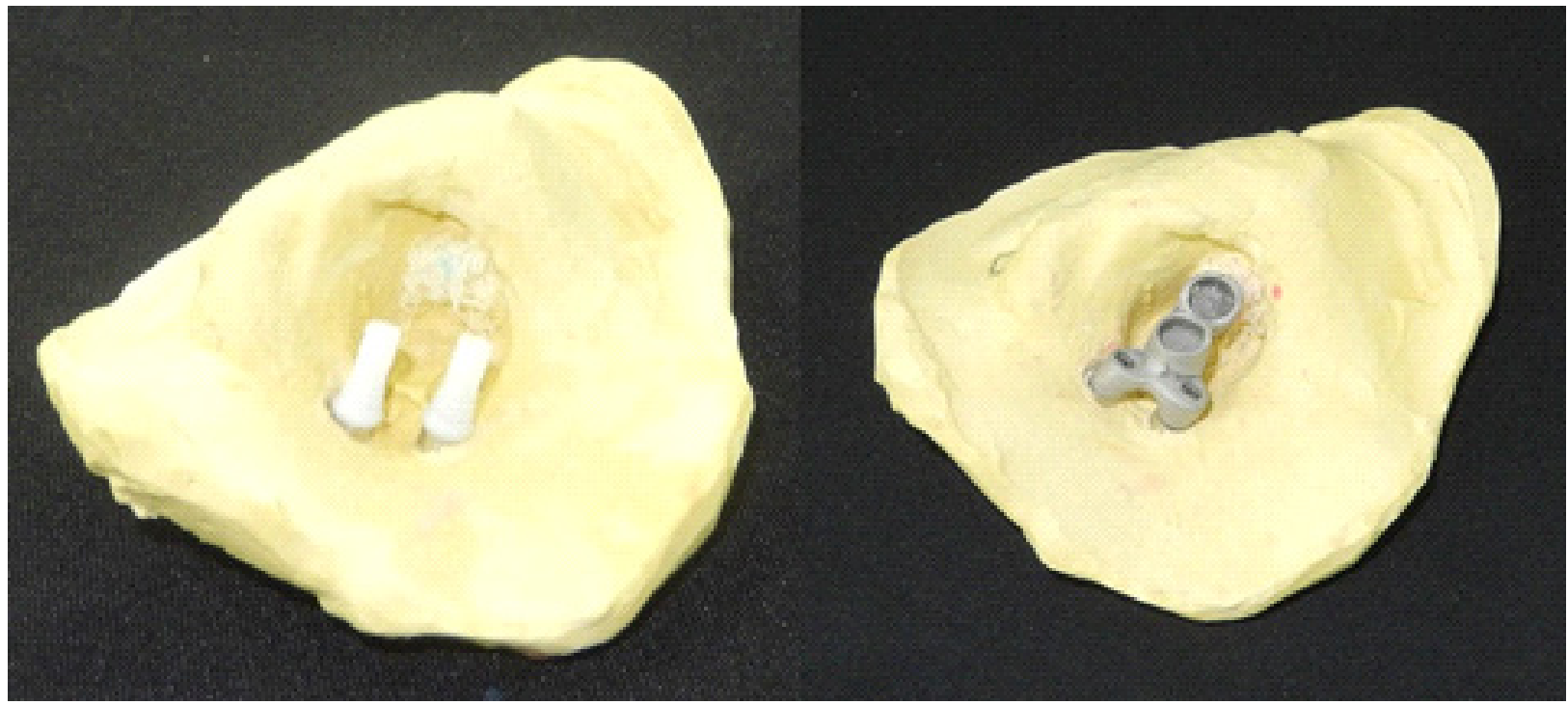

Figure 4. Laboratory phase of installing prosthetic cylinders and casting a metal bar with cocoons for magnets. 
After setting the material, the transfer agents were unscrewed, allowing the removal of the mold. Then, the analogs of the intermediates were screwed into the transfer components and the mold was cast with type IV plaster (Special Stone Plaster Durone Type IV, Dentsply, Petrópolis, RJ, Brazil) to obtain the working model. Minipillar guards were screwed over the intermediaries and the recommendations and postoperative medications were passed on to the patient.

After obtaining the working model, the prosthetic cylinders were screwed over the analogs of the model intermediates (figure 4), cut and, with Duralay acrylic resin, the bar model and the cocoons that will form the anchoring system for the prosthesis. After testing this on the patient, the anchoring system was sent to the laboratory for casting (figure 5). When fused, it was tested on the patient and, on the cocoons, two neodymium magnets were cemented with colorless acrylic resin (Autopolymerizable Acrylic Resin, VipFlash, Pirassununga, SP, Brazil).

A $20 \mathrm{~mm}$ polyester strip was placed over the anchoring system, positioned on the work model, and on it two neodymium magnets, which were joined with colorless acrylic resin, thus forming the acrylic counter-bar that would be fixed to the nasal prosthesis.

The anchoring system was screwed to the patient with the cemented magnets, the acrylic counter-bar with the magnets was positioned and the prosthetic piece previously sculpted in dental pink wax No. 7 (Cera Plana No. 7, ASFER Indústria Química Ltda, São Caetano do Sul,
São Paulo) on the working model, was positioned so that the set could be tested on the patient, checking possible interference between the components of the anchoring system, the acrylic counter-bar and the sculpture of the piece.

To perform the prosthetic step, the material of choice was the self-curing acrylic resin $n^{\circ} 69$ (Dencôr Classic Polymerizing Resin, Campo Limpo Paulista, SP, Brazil) added with pigments based on synthetic iron oxide (CHESS Powder Pigment LANXESS, São Paulo, SP, Brazil) (IMAGE 18). The acrylic resin was prepared by adding pigments to the acrylic resin in order to reproduce the base color of the patient's skin. For this, during the addition of the pigments, small portions were polymerized in order that the base color of the patient was reproduced and there was chromatic compatibility in the intrinsic pigmentation.

The acrylic resin powder added to the pigments in the base color together with the wax sculpture were sent to the laboratory for the acrylic of the prosthetic part. After acrylization, the anchoring system was screwed to the patient, the acrylic counter-bar was positioned and a small portion of colorless acrylic resin was manipulated and placed on the acrylic counter-bar, and the prosthetic piece was placed in order to that the acrylic counter-bar be attached to the prosthesis. After the polymerization of the colorless acrylic, finishing and polishing were performed on the internal surface of the prosthetic part.

Checking the peripheral adaptation of the piece, it was noted the lack of contact with the skin in some

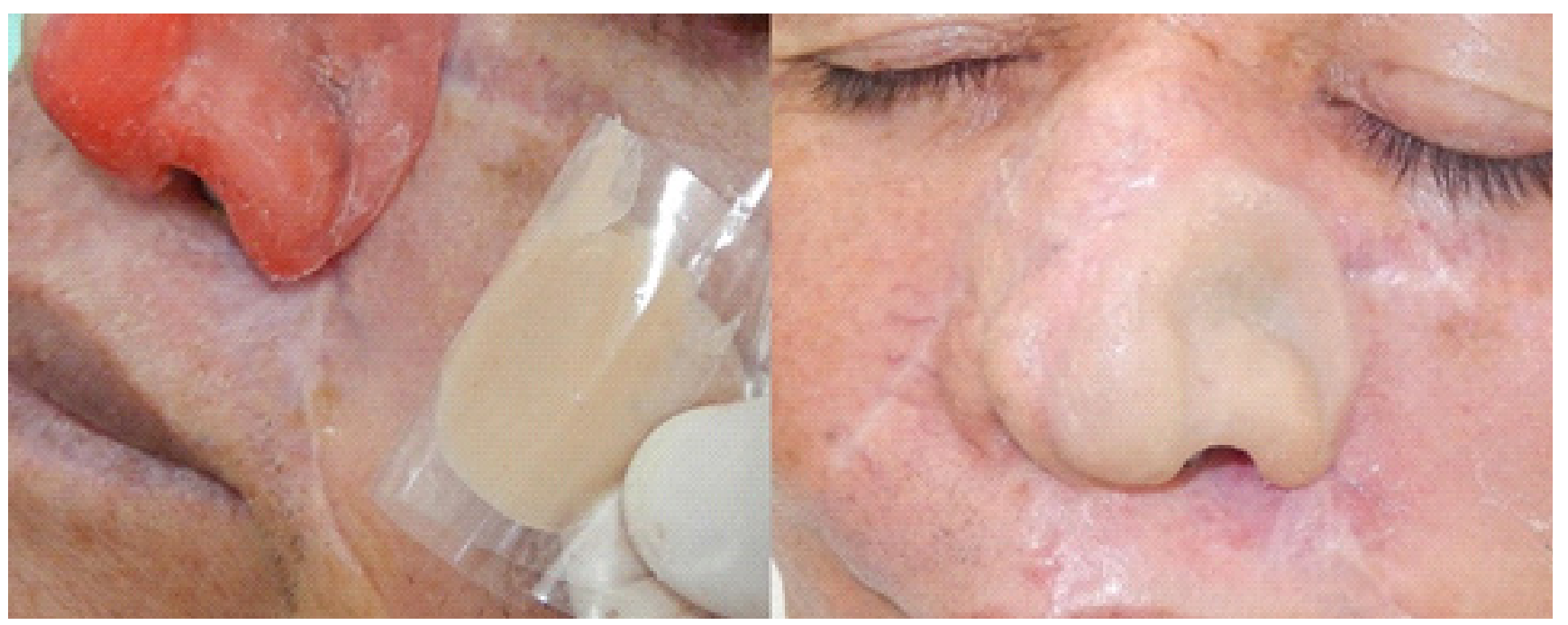

Figure 5. Waxing test step, color selection and acrylic resin prosthesis test (without final characterization). 
regions, as well as the lack of material in the region of the wing of the nose. To correct such defects, the skin of the patient was isolated with solid petroleum jelly, acrylic resin in the base color was prepared and then repackaged in areas without peripheral adaptation, in addition to anatomical repair of the nose wing (figure 5).

For extrinsic pigmentation, colorless acrylic resin powder was added with a monomer, forming a fluid mixture and, to this, pigments based on synthetic iron oxide were added, thus producing a pigment based on acrylic resin with chemical compatibility with the prosthetic piece of acrylic resin, allowing the characterization of the prosthesis, giving, in addition to a color similar to that of the patient, as the polymerization and increase of the viscosity of the mixture occurred, the piece was given a superficial texture (figure 6).

\section{DISCUSSION}

Malignant skin neoplasms have a high rate of recurrence and require clinical monitoring of the injured area, making the choice for prosthetic reconstruction the best alternative for defect reconstruction [12].

The facial prosthesis has some advantages over plastic surgery, such as early alloplastic reconstruction of the defect, speed in restoring the patient's appearance, reducing the cost of treatment and operating time, restoring function, protecting exposed tissues, and allowing patients to be reinserted in the context of social contact (which they were excluded due to the appearance of the facial defect), acting as a benefit for the patient's psychological recovery regarding the improvement of their self-esteem [12-15].

Alloplastic facial reconstruction is performed using facial prostheses commonly made of materials such as silicone and acrylic resin. The silicone prosthesis provides good aesthetic quality, softness and texture similar to human skin, admits intrinsic and extrinsic pigmentations, in addition to an easy-to-execute technique. However, it does not have favorable mechanical properties and suffers deterioration in a short time due to factors such as sun exposure, pollution, changes in humidity and temperature, use of chemical cleaning agents and direct application of adhesive, since it does not easily adhere to others materials. It has a high cost and, since it is of foreign manufacture, acquisition is difficult in our country [12,14,16-19].

In the exposed clinical case, the material of choice for making the facial prosthesis was acrylic resin. The resin prostheses, in addition to allowing extrinsic and intrinsic pigmentations, offer rigidity and reduce the possibility of tearing, have greater durability, good tolerance for the remaining fabrics, facilities in the manufacture of the piece and handling, lower cost, and are still easily obtained and passable of repairs by repacking the part. However, it does not have adequate aesthetic properties as it does not allow texture similarity to human skin and has limited use by some facial prostheses because of its rigidity, making it difficult to adapt the prosthesis edges to the remaining facial tissues [18-22].

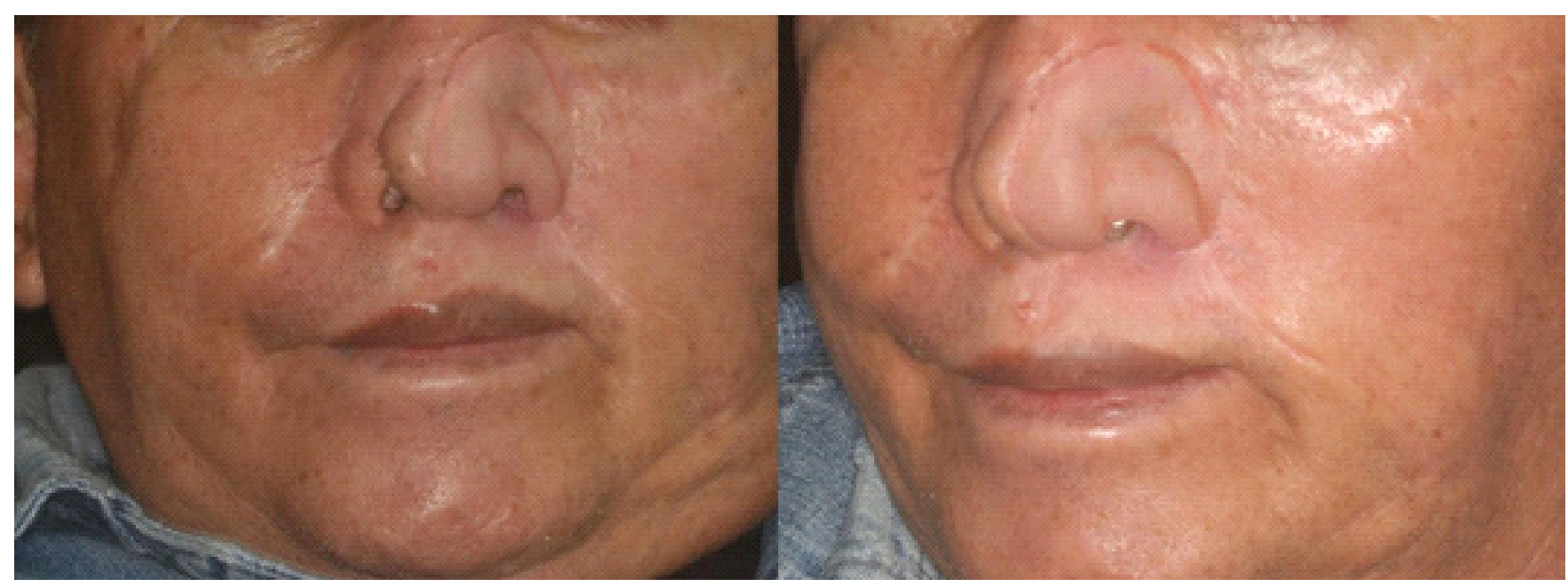

Figure 6. Front and side view of implant-retained acrylic prosthesis with finished magnetic fixation. 
Retentions for facial prostheses can be adhesive or obtained through osseointegrated systems in implantretained prostheses. The prosthesis with adhesive retention has disadvantages such as the need for good manual dexterity to be positioned correctly, in addition to the possibility of skin irritation due to direct and constant contact with the adhesive, reducing the time of effectiveness of the adhesive film, due to skin greasiness and sweating, therefore requiring multiple applications during the day, damaging the prosthesis margins because of the repeated application of the adhesive $[23,24]$.

Extraoral implants exhibit comparable or better longevity than that obtained in the oral cavity and the benefits also include increased retention and stability of the prosthesis, decreased adverse reactions (because it consists of biocompatible material), dispensing with the use of adhesives for the retention of prostheses, allows better installation of facial prostheses, hygiene and comfort. Among the disadvantages, we can mention the need for a new surgical time for its placement, adequate bone condition for its installation, high cost, besides having debatable use in irradiated patients [25].

The mechanical fixation using magnets in the prosthesis and in the anchorage system allows the use of isolated implants, due to the lower incidence of functional loads, it does not present significant prosthetic instability, as it does not present direct contact with body fluids, the magnet has reduced or no corrosion, due to the magnetic force, the installation of the prosthesis is automatically carried out when the prosthesis and the anchorage system are approached, the magnets are easily replaced, when necessary, and, despite the small size, they present strong magnetic forces of attraction between the prosthesis and the anchoring system, facilitating orientation during the installation of the prosthesis $[26,27]$.

Despite the mentioned advantages, mechanical retention using magnets requires a longer time for the construction of the anchoring system, it is a more costly retention method for the patient and requires an efficient cleaning around the prosthetic abutments, thus allowing the reduction the possibility of peri-implant inflammatory processes.

Cleaning and care with the prosthesis are essential for its longevity and maintenance of the health quality of the surrounding tissues, especially in the nasal region, due to the production of inherent secretion from the underlying tissues. The patient was instructed to sanitize, daily, with water and neutral soap, both in the external and internal portions of the prostheses, being alerted about undesirable factors associated with the longevity of the prostheses such as solar radiation, pollution and degradation by microrganisms [12,14,28-31].

For the care of adjacent tissues, it was recommended to remove the prosthesis before bed to avoid trauma and contamination by bacteria and fungi due to the presence of moisture resulting from breathing, in addition to the possibility of the development of tissue inflammation due to the pressure caused by the prosthesis. The instructions also included cleaning the skin with water and mild soap, while for mucous surfaces cleaning with saline solution was recommended $[14,30]$.

As it is an implant-retained prosthesis, the patient was instructed to perform daily cleaning around the prosthetic abutments with water, neutral soap and gauze and/or cotton swabs to remove the formed sebaceous/ bacterial crust and secretions of accumulated mucous origin responsible for inflammatory tissue reactions.

The patient received guidance on return and follow-up. Periodic consultations three to six months after the installation of the prosthetic parts were recommended to evaluate the prosthesis for retention, stability, support and examination for the analysis of the integrity of the supporting tissues [32].

\section{CONCLUSION}

It is concluded that the alloplastic reconstruction of maxillofacial defects allows the anatomical, aesthetic, functional rehabilitation and allows the dignity of patients with the defect to be restored and improves their quality of life from the moment it is reinserted in society.

\section{Collaborators}

CRG Amaral, conductor of the clinical case and author of the article. MB Ramos and RR Regis, responsible for the textual correction of the article. MGM Fernandes, responsible for text formatting and adaptation to the magazine's rules. TC Diniz, responsible for text formatting and adaptation to the magazine's rules. WA Negreiros, coordinator of the Face Defects Center extension project and advisor to the main author. 


\section{REFERENCES}

1. Goiato MC, Vedonatto E, Mazaro JVP, Hamatta HG, FILHO HG, Falcón RM, et al. Técnicas de confección de prótesis faciales. Rev Cubana Estomatol. 2009;46(1).

2. Antunes $A A$, Carvalho RWF, Lucas Neto AL, Loretto NRM, Silva EDO. Utilização de implantes osseointegrados para retenção de próteses buco-maxilo-faciais: revisão de literatura. Rev Cir Traumatol Buco-maxilo-fac. 2008;8(2):09-14.

3. Simões FG, Reis RC, Dias RB. A especialidade de prótese bucomaxilofacial e sua atuação na odontologia. Rev Sul-Bras Odontol. 2009;6(3):327-331.

4. Bajaj GB, Shambharkar V. The eyegglass frame retained nasal prosthesis after parcial rhinectomy: a clinical report. JPPA. 2013;1(2):113-116.

5. Did LL, Oliveira JAO. Reabilitação bucomaxilofacial - uso de próteses e implantes osseointegrado. São Paulo: Artes Médicas; 2002.

6. Instituto Nacional do Câncer (INCA). Síntese de Resultados e comentários: câncer de pele. 2016 [citado 2018 Fev 10]. Disponível em: <http://www.inca.gov.br/estimativa/2016/ sintese-de-resultados-comentarios.asp $>$.

7. Flood TR, Russell K. Reconstruccion of nasal defects with implant-retained nasal prostheses. Br J Oral Maxillofac Surg. 1998;36(5):341-345.

8. Lemon JC, Kiat-Amnauy S, Gettleman L, Martin JW, Chambears MS. Facial prosthetic rehabilitation: preprosthetic surgical techniques and biomaterials. Curr Opin Otolaryngol Head Neck Surg. 2005;13(4):255-262.

9. Laitano FF, Teixeira LF, Siqueira EJ, Alvarez GS, Escobar DJ, Martins OMP. Uso de retalho cutâneo para reconstrução nasal após ressecção neoplásica. Rev Bra Cir Plást. 2012;27(2):212-222.

10. Cardoso MSO, Souza EHA, Cardoso AJO, Lobo JS, Cardoso SO. Importância da reabilitação protética nasal: Relato de caso. Rev Cir Traumatol Buco-Maxilo-Fac. 2006;6(1):43-46.

11. Brown KE. Fabrication of a nose prosthesis. J Prosthet Dent. 1971; 26(5):543-554. http://dx.doi.org/10.1016/0022-3913(71)90015-1

12. Neves ACC, Patrocínio MC, Claro CA, Werkman C. Prótese nasal. Rev Odonto. 2006;14(27-28):105-110.

13. Rode R, D'Almeida NF, Neves ACC, Penna LAP, Rode SM. Próteses bucomaxilofaciais. In: Mélega JM. Cirurgia plástica: fundamentos e arte. Cirurgia reparadora de cabeça e pescoço. Rio de Janeiro: 2002. p. 317-324.

14. Huband M. Prothestic reabilitation Dermatol Clin. 2011;29(2):325330. http://dx.doi.org/10.1111/j.1708-8208.2010.00328.x

15. Goiato MC, Mancuso DN, Zuccolotti BCR, Murakawa AC, Lima DC, Santos DM, et al. Retention and processing methods of nasal prosthesis. J Coll Physicians Surg Pak. 2012;22(11):716-719.

16. Giustinoa AM, Saboya ACL, Miracca R, Brito e Dias R. Prótese nasal - Caso clínico: estudo comparative entre materiais. Odonto. 1993;2(11):335-338.

17. Neves ACC, Villela LC. Desenvolvimento de uma escala em silicone para tons de pele humana. Rev Odontol Univ São Paulo. 1998;2(1):57-63.
18. Waters MGJ, Jagger RG, Polyzois GL. Wattability of silicone rubber maxilofacial prosthetic materials. J Prosthetic Dent. 1999;81(4):439443. http://dx.doi.org/10.1016/s0022-3913(99)80011-0

19. Martins APVB, Barbosa CMR. Associação de técnicas para reconstrução de deformidade nasal. Rev Odontol Bras Central. 2014;23(65):64-65.

20. Rodrigues S, Shenoy VK, Shenoy K. Prosthetic reabilitation of patient after parcial rhinectomy: a clinical report. J Prosthet Dent. 2005;93(2):125-128. http://dx.doi.org/10.1016/j. prosdent.2004.10.021

21. Khindria SK, Bansal S, Kansal M. Maxillofacial prosthetic materials- Review Article. J Indian Prosthodont Soc Karnal. 2009;9(1):2-5. http://dx.doi.org/10.7860/JCDR/2014/9229.5244

22. Maller U. Karthik S, Maller S. Maxillofacial Prosthetic Materials. JIADS. 2010;1(2):25-30. http://dx.doi.org/10.4103/22293019.166094

23. Patrocínio MC, Marchini L, Araújo MA. Adesivos para pele em prótese bucomaxilofacial: revisão da literature. Odontol USF. 2000;18(1):57-61.

24. Seignemartin CP, Dib LL, Oliveira J. A reabilitação facial com próteses convencionais e sobre implantes osseointegráveis. ImplantNews. 2004;1(2):161-168.

25. Ciocca L, Fantini M, Marchetti C, Scotti R, Monaco C. Immediate facial reabilitations in cancer patients using CADCAM and rapid prototyping technology: a pilot study. Support Care Cancer. 2010;18:723-728. http://dx.doi.org/10.1007/ s00520-009-0676-5

26. Watson C, Tinsley D, Sharma S. Implant complications and failures: the complete overdenture. Dental Update. 2001;28(5):234-238. http://dx.doi.org/10.12968/denu.2001.28.5.234

27. Bhat V. A close-up on obturators using magnets. J Indian Prosthodont Soc. 2005;5(3):114-118.

28. Rezende JRV, Oliveira JAP, Dias RB. Prótese bucomaxilofacial: conceitos básicos e práticas de laboratório. São Paulo: Editora Sarvier; 1986.

29. Goiato MC, Fernandes AUR, Trevisan CL, Neto SC. Reconstrução da pirâmide nasal com prótese. Rev $A B O$. 2005;13(3):166-170.

30. Goiato MC, Zucolotti BCR, Manucuso DN, Dos Santos DM, Pellizzer EP, Verri FR. Care and cleaning of maxillofacial prostheses. J Craniofac Surg. 2010;21(4):1279-1273. http:// dx.doi.org/10.1097/SCS.0b013e3181e1b431

31. Eleni PN, KrokidA M, Polizoys G, Gettleman L, Bisharat G. Effects of outdoor weathering on facial prosthetic elastomers. Odontology. 2011;99(1):68-76.

32. Meghna C, Aparna IN, Dhanasekar B, Sarala C. Fabrications of a hollow facial prosthesis for rehabilitating a large facial defect. Using an innovative double packing technique - A case report. IJDHS. 2015;2(4):1036-1043.

Received on: 5/11/2018

Approved on: 23/9/2020

Final version resubmitted on: 30/10/2020 